\title{
Progression of Aortic Stenosis and Long-term Follow-Up in Women
}

Rakhee Makhija ${ }^{1,2}$, Sandhya Venugopal ${ }^{2}$, Nene Takahashi ${ }^{3}$, Mrudula Guthikonda ${ }^{4}$, Lavanya Mandal ${ }^{2}$, Yasameen Alismail ${ }^{2}$, Sura Abbas $^{2}$, Ali A Mahdi², William R. Lewis², Machelle Wilson', Ezra A. Amsterdam²*

${ }^{1}$ Department of Internal Medicine, Regional Medical Center, San Jose, CA

${ }^{2}$ Division of Cardiovascular medicine, Department of Internal Medicine, University of California (Davis) Medical Center, Sacramento, CA

${ }^{3}$ Western University of Health Sciences, Pomona, CA

${ }^{4}$ Kaiser Permanente Medical Group, Sacramento, CA

${ }^{5}$ Clinical and Translational Science Center, Department of Public Health Sciences, Division of Biostatistics, University of California, Davis

*Corresponding Author: Ezra A Amsterdam, 4860 Y Street, Ellison Building, Suite 2820, Sacramento, CA 95817

Received Date: February 26, 2021; Accepted Date: April 19, 2021 ; Published Date: April 26,2021

Citation: Rakhee Makhija., Sandhya Venugopal., Nene Takahashi., Mrudula Guthikonda., Lavanya Manda., et al., (2021) Progression of Aortic Stenosis and Long-term Follow-Up in Women. J. Clinical Cardiology and Cardiovascular Interventions, 4(8); Doi:10.31579/2641-0419/147

Copyright: (c) 2021 Ezra A Amsterdam, This is an open-access article distributed under the terms of the Creative Commons Attribution License, which permits unrestricted use, distribution, and reproduction in any medium, provided the original author and source are credited.

\begin{abstract}
Data on the rate of progression of aortic stenosis (AS) in women are limited. We retrospectively studied 95 female patients (age $75 \pm$ $13 \mathrm{yrs}$ ) with aortic valve area (AVA) $<2.0 \mathrm{~cm}^{2}$ (mild AS $1.5-1.9 \mathrm{~cm}^{2}$, moderate AS $1.0-1.4 \mathrm{~cm}^{2}$, severe AS $<1.0 \mathrm{~cm}^{2}$ ). All patients underwent serial transthoracic echocardiography. We determined annual AVA decrease (rate of AS progression) by 3 approaches, each of which was applied to the entire cohort: 1) as a single group; 2) in the 3 subgroups of mild, moderate and severe AS; and 3) in the rapid and slower progressors. Study endpoints were aortic valve replacement (AVR) and all-cause mortality. The mean duration of follow-up was $4.5 \pm 2.9$ years. Mean rate of reduction in AVA for the total study group was $0.14 \pm 0.16 \mathrm{~cm}^{2} / \mathrm{yr}$ and was directly related to presence of hypertension and baseline AVA, and inversely related to follow-up duration (all p<0.05). The annualized decrease in AVA for each of the subgroups of mild, moderate and severe AS at baseline was $0.21 \pm 0.31 \mathrm{~cm}^{2}, 0.13 \pm 0.11 \mathrm{~cm}^{2}, 0.11 \pm 0.09 \mathrm{~cm}^{2}$, respectively ( $\mathrm{p}<0.0001$ ). Rapid progression of AS (decrease in AVA $\geq 0.20 \mathrm{~cm}^{2} / \mathrm{yr}$ ) occurred in $21 \%$ of patients ( $\mathrm{n}=20$ ) and was associated with baseline hypertension $(\mathrm{p}=0.03$ ) and inversely related to follow-up duration ( $\mathrm{p}=0.0007$ ). Rapid progressors had shorter follow-up than slower progressors (20 vs. 42 mos, $\mathrm{p}=0.002$ ). Event-free survival with end-points of death ( $\mathrm{n}=65$ ) or surgical/transcatheter AVR $(\mathrm{n}=24)$ at 1,3 , and 5 years, respectively, was $93 \%, 66 \%$ and $40 \%$ for mild AS; $96 \%, 72 \%$ and $48 \%$ for moderate AS; and $93 \%, 38 \%$ and $24 \%$ for severe AS. Thus, event-free survival at 5 years in patients with baseline severe AS was approximately half that of patients with AS of mild or moderate severity. In addition, event-free survival at 1 year in slower progressors was $92 \%$ and in rapid progressors was $70 \%$.
\end{abstract}

Key words: aortic stenosis in women; aortic stenosis progression; valvular heart disease; aortic stenosis prognosis

Running head: Aortic stenosis in women

\section{Introduction}

Aortic stenosis (AS) is the most common valvular heart disease in developed countries, affecting $2-7 \%$ of persons $>65$ years old [1]. Many of the factors associated with development of AS parallel those for atherosclerotic vascular disease [2]. However, there is a paucity of data on the relation of these and other factors to progression of AS specifically in women because, with few exceptions, women have been studied in mixed gender populations [3-14]. Rate of progression of AS is an essential aspect of patient management, especially in terms of valve replacement [2-8]. Our study aimed to determine: rate of progression of AS in women; its relation to mild, moderate and severe baseline AS: and the prevalence of those with rapid AS progression. Study endpoints were mortality and aortic valve replacement (AVR).

\section{Methods}

We queried the echocardiographic database of the University of California, Davis, Medical Center, to identify consecutive female patients with at least 2 transthoracic echocardiograms (TTE) at $\geq 3$-month intervals and aortic valve area (AVA) $<0.20 \mathrm{~cm}^{2}$ at study entry. Patients were followed during the interval from 2002 to 2017. Clinical data were obtained from patients' electronic medical records including age, coronary artery disease (history of myocardial infarction, coronary 
revascularization), diabetes, hypertension (blood pressure $\geq 140 / 90$ mmHg [15]), dyslipidemia, chronic kidney disease and smoking. Laboratory data included basic serum chemistries, hemoglobin A1c and lipid panel.

Transthoracic echocardiograms were performed with standard techniques according to the American Society of Echocardiography guidelines [1618]. Left ventricular outflow tract diameter and gradient were measured in the parasternal long axis view with pulsed Doppler flow. The peak systolic transaortic valve jet velocity was determined from the continuous Doppler flow velocity signal across the aortic valve in apical views and the peak and mean aortic valve systolic gradients were calculated from the modified Bernoulli equation. AVA was determined from the continuity equation [19]. The degree of aortic valve calcification was estimated semi-quantitively from parasternal short axis views and recorded as mild (isolated, small spots), moderate (multiple larger spots), and severe (extensive thickening and calcification of all 3 aortic valve leaflets) [6]. Left ventricular ejection fraction was calculated by the apical biplane method of disks. The degree of AS was classified according to current American College of Cardiology/American Heart Association guidelines into mild (AVA 1.5-1.9 $\mathrm{cm}^{2}$ ), moderate (AVA $1.0-1.5 \mathrm{~cm}^{2}$ ) and severe AS (AVA $<1.0 \mathrm{~cm}^{2}$ ) [20]. AS progression in each patient was measured as annual change in AVA $\left(\mathrm{cm}^{2} / \mathrm{yr}\right)$ during the interval from the TTE at study entry to the most recent follow-up TTE (total change in AVA divided by follow-up interval [years]). For additional analyses, patients were divided into rapid progressors (annual AVA decrease of $\geq 0.20 \mathrm{~cm}^{2} / \mathrm{yr}$ ) and slower progressors (annual AVA decrease of $<0.20$ $\mathrm{cm}^{2} / \mathrm{yr}$ ) [21]. Data on AVR and all-cause mortality were obtained from patients' electronic medical records.

\begin{tabular}{|c|c|c|c|c|}
\hline & $\begin{array}{c}\text { Total } \\
(\mathrm{n}=95)\end{array}$ & $\begin{array}{c}\text { Mild AS } \\
(n=15)\end{array}$ & $\begin{array}{c}\text { Moderate AS } \\
(n=50)\end{array}$ & $\begin{array}{c}\text { Severe AS } \\
(\mathbf{n}=\mathbf{3 0})\end{array}$ \\
\hline Age (yrs) & $74.8 \pm 12.7$ & $77.1 \pm 12.6$ & $74.5 \pm 11$ & $74.2 \pm 15.6$ \\
\hline Follow-up (mos.) & $54.7 \pm 35.3$ & $62.3 \pm 46.5$ & $60 \pm 31.8$ & $42.2 \pm 32.2$ \\
\hline \multicolumn{5}{|l|}{ Co-morbidities (n, \%) } \\
\hline CAD & $42(44.2 \%)$ & $9(60 \%)$ & $17(34 \%)$ & $16(53.3 \%)$ \\
\hline Diabetes mellitus & $22(23 \%)$ & $3(20 \%)$ & $11(22 \%)$ & $8(26.6 \%)$ \\
\hline Dyslipidemia & $39(41 \%)$ & $5(33.3 \%)$ & $22(44 \%)$ & $12(40 \%)$ \\
\hline Hypertension & $51(53.7 \%)$ & $12(80 \%)$ & $25(50 \%)$ & $14(46.7 \%)$ \\
\hline Hemodialysis & $9(9.5 \%)$ & $1(6.6 \%)$ & $5(10 \%)$ & $3(10 \%)$ \\
\hline Current smoker & $28(31.1 \%)$ & $4(26.6 \%)$ & $17(34 \%)$ & $7(23.3 \%)$ \\
\hline \multicolumn{5}{|c|}{ Laboratory data (mean $\pm S D$, range $)$} \\
\hline A1c $(\%)$ & $\begin{array}{l}6.5 \pm 1.2 \\
(4.8-11)\end{array}$ & $\begin{array}{l}6.4 \pm 1.1 \\
(5.2-9.4)\end{array}$ & $\begin{array}{l}6.4 \pm 1.1 \\
(4.8-9.2)\end{array}$ & $\begin{array}{l}6.6 \pm 1.4 \\
(5.1-11)\end{array}$ \\
\hline $\begin{array}{l}\text { Serum creatinine } \\
(\mathrm{mg} / \mathrm{dL})\end{array}$ & $\begin{array}{c}1.45 \pm 1.46 \\
(0.5-7.5)\end{array}$ & $\begin{array}{c}1.56 \pm 1.47 \\
(0.7-6.7)\end{array}$ & $\begin{array}{c}1.42 \pm 1.4 \\
(0.5-7.5)\end{array}$ & $\begin{array}{c}1.45 \pm 1.56 \\
(0.5-7.2)\end{array}$ \\
\hline $\begin{array}{l}\text { eGFR } \\
\left(\mathrm{mL} / \mathrm{min} / 1.73 \mathrm{~m}^{2}\right)\end{array}$ & $\begin{array}{c}53.5 \pm 25 \\
(5-117)\end{array}$ & $\begin{array}{c}45.8 \pm 18.8 \\
(5.9-80)\end{array}$ & $\begin{array}{c}54.2 \pm 24.2 \\
(5.8-117)\end{array}$ & $\begin{array}{c}56.35 \pm 28.68 \\
(5.5-114)\end{array}$ \\
\hline $\begin{array}{l}\text { LDLc } \\
(\mathrm{mg} / \mathrm{dL})\end{array}$ & $\begin{array}{c}106 \pm 42.3 \\
(35-212)\end{array}$ & $\begin{array}{c}94.3 \pm 31.8 \\
(55-139)\end{array}$ & $\begin{array}{c}107.4 \pm 43.7 \\
(35-212)\end{array}$ & $\begin{array}{c}109.2 \pm 45.06 \\
(39-205)\end{array}$ \\
\hline \multicolumn{5}{|l|}{ Echocardiogram data } \\
\hline $\operatorname{AVA}\left(\mathrm{cm}^{2}\right)$ & $1.2 \pm 0.3$ & $1.65 \pm 0.09$ & $1.27 \pm 0.15$ & $0.81 \pm 0.14$ \\
\hline $\operatorname{LVEF}(\%)$ & $60.5 \pm 7.9$ & $60 \pm 7.3$ & $61.2 \pm 7.13$ & $59.6 \pm 9.6$ \\
\hline $\begin{array}{l}\text { Severe calcification (n, } \\
\text { patients } \%)\end{array}$ & $43(45.3 \%)$ & $6(40 \%)$ & $21(42 \%)$ & $16(53.3 \%)$ \\
\hline
\end{tabular}

Table 1: Patient characteristics

AS, Aortic stenosis; CAD, coronary artery disease; eGFR, estimated glomerular filtration rate, LDLc, low-density lipoprotein cholesterol, AVA,

Statistical tests were performed with Stata 13.0 MP (StataCorp LP, College Station, TX, USA). Continuous data are presented as mean \pm SD and range or percent and their differences were tested by unpaired t-test. Categorical data were compared with $\mathrm{X}^{2}$ test. Reverse step-wise multiple regression analysis was used to determine independent predictors of AVA reduction. Logistic regression analysis was performed to assess predictors of rapid AS progressors. A difference of $p<0.05$ was considered significant. Event-free survival was depicted by Kaplan-Meier curves according to AS severity and rapidity of progression with log-rank test to compare differences between groups.

\section{Results}

The clinical characteristics of the study group are shown in Table 1 . Average age of the patients was 75 years and included a wide range. Follow-up interval was more than 4.5 years. A majority of the women fulfilled criteria for moderate baseline AS and almost one-third had severe AS. More than half of the patients had $\geq 2$ cardiac risk factors, the most common of which was hypertension; almost half of the patients had coronary artery disease and one-third were current smokers (Table 1).

Number of TTEs per patient was approximately 3 and the average interval between any 2 TTEs was 10 months. The baseline AVA for the entire cohort was $1.2 \mathrm{~cm}^{2}$ and average left ventricular ejection fraction was normal (Table 1). Average rate of decrease in AVA for the total cohort was approximately $0.14 \mathrm{~cm}^{2} / \mathrm{yr}$. Annualized decrease in AVA for each of the 3 AS subgroups was greatest in patients with mild baseline AS (0.21 $\mathrm{cm}^{2} / \mathrm{yr}$ and less in patients with moderate $\left(0.13 \mathrm{~cm}^{2} / \mathrm{yr}\right)$ and severe AS $\left(0.11 / \mathrm{cm}^{2} / \mathrm{yr}\right) \quad(\mathrm{p}<0.001)$. About half of our patients had severe calcification and thickening of all 3 aortic valve leaflets (Table 1).

\footnotetext{
AS, Aortic stenosis; CAD, coronary artery disease; eGFR, estimated glomerular filtration rate, LDLc,
aortic valve area; LVEF, left ventricular ejection fraction.
} 
Progression to severe AS occurred in $26 \%$ of patients with initially mild baseline AS and in $66 \%$ with initially moderate AS. Factors that univariately correlated to annualized decrease in AVA were hypertension and follow-up duration (both $\mathrm{p}<0.05$ ) (Table 2).

\begin{tabular}{|l|c|c|}
\hline \multicolumn{3}{|c|}{ Annual AVA decrease } \\
\hline Variable & $\boldsymbol{r}$ & $\boldsymbol{P}$ \\
\hline Age & 0.007 & 0.59 \\
\hline Follow-up duration & $\mathbf{- 0 . 0 0 1}$ & $\mathbf{0 . 0 0 2}$ \\
\hline Hypertension & $\mathbf{0 . 0 7}$ & $\mathbf{0 . 0 2 5}$ \\
\hline CAD & -0.008 & 0.78 \\
\hline Diabetes mellitus & -0.015 & 0.59 \\
\hline Dyslipidemia & -0.054 & 0.12 \\
\hline Hemodialysis & 0.04 & 0.46 \\
\hline Current smoker & -0.041 & 0.27 \\
\hline Serum creatinine & 0.006 & 0.53 \\
\hline eGFR & -0.006 & 0.3 \\
\hline Baseline AVA & 0.10 & 0.04 \\
\hline $\begin{array}{l}\text { Aortic valve } \\
\text { calcification }\end{array}$ & -0.03 & 0.25 \\
\hline $\begin{array}{l}\text { Change in peak aortic } \\
\text { velocity }\end{array}$ & 0.1 & 0.002 \\
\hline LVEF & 0.0009 & 0.64 \\
\hline
\end{tabular}

Table 2: Univariate correlates of annual decrease in AVA

$\boldsymbol{A V A}$, aortic valve area; $\boldsymbol{C A D}$, coronary artery disease; $\boldsymbol{e} \boldsymbol{G F R}$, estimated glomerular filtration rate; $\mathbf{L V E F}$, left ventricular ejection fraction.

The latter factors were independently associated with AS progression. There was no correlation of age, coronary artery disease, diabetes, dyslipidemia, current smoking, chronic kidney disease or aortic valve calcification with AS progression.

Patients with rapid AS progression (decrease in AVA $\geq 0.20 \mathrm{~cm}^{2} / \mathrm{yr}$ ) comprised approximately one-fifth of our cohort of 95 patients. Average decrease in AVA was $>0.30 \mathrm{~cm}^{2} / \mathrm{yr}$ for rapid progressors and approximately one-fourth this rate $\left(0.08 \mathrm{~cm}^{2} / \mathrm{yr}\right)$ in the slower progressors. Compared to slower progressors, the rapid progressors had more frequent hypertension, larger baseline AVA and shorter follow-up (all p<0.05) (Table 3).

\begin{tabular}{|l|c|c|c|}
\hline & Rapid (n=20) & Slower (n=75) & P \\
\hline Age (yrs) & $77.1 \pm 12.6$ & $74.2 \pm 12.8$ & 0.37 \\
\hline Follow-up (mos) & $20 \pm 9.3$ & $42 \pm 32$ & 0.002 \\
\hline Hypertension (n, \%) & $15(75 \%)$ & $36(48 \%)$ & 0.03 \\
\hline CAD (n, \%) & $9(45 \%)$ & $33(44 \%)$ & 0.93 \\
\hline Diabetes mellitus (n,\%) & $3(27 \%)$ & $21(39 \%)$ & 0.46 \\
\hline Dyslipidemia $(\mathrm{n}, \%)$ & $5(29 \%)$ & $34(49 \%)$ & 0.14 \\
\hline Hemodialysis $(\mathrm{n}, \%)$ & $2(10 \%)$ & $7(9 \%)$ & 0.92 \\
\hline Current smoker $(\mathrm{n}, \%)$ & $5(26 \%)$ & $23(32 \%)$ & 0.61 \\
\hline Creatinine $(\mathrm{mg} / \mathrm{dL})$ & $1.5 \pm 1.3$ & $1.4 \pm 1.5$ & 0.76 \\
\hline eGFR $\left(\mathrm{mL} / \mathrm{min} / 1.73 \mathrm{~m}^{2}\right)$ & $46.5 \pm 22$ & $55.4 \pm 49$ & 0.15 \\
\hline No. echoes & $2.6 \pm 0.9$ & $3.1 \pm 1.2$ & 0.50 \\
\hline LVEF $(\%)$ & $60.5 \pm 7.6$ & $60.6 \pm 8.1$ & 0.96 \\
\hline Baseline AVA $\left(\mathrm{cm}^{2}\right)$ & $1.3 \pm 0.28$ & $1.15 \pm 0.31$ & 0.06 \\
\hline
\end{tabular}

Table 3: Comparison of rapid vs slow progressors

$\boldsymbol{C A D}$, coronary artery disease; $\boldsymbol{e} \boldsymbol{G F R}$, estimated glomerular filtration rate; echoes, echocardiograms; LVEF, left ventricular ejection fraction; $\boldsymbol{A} \boldsymbol{V A}$, aortic valve area.

Results of logistic regression analysis depicting factors affecting rapid progression is shown in (Table 4). 


\begin{tabular}{|l|l|l|}
\hline \multicolumn{3}{|l|}{} \\
\hline Variable & Odds ratio (95\% CI) & P \\
\hline Age & $1.02(0.97-1.06)$ & 0.37 \\
\hline Follow-up duration (months) & $\mathbf{0 . 9 5}(\mathbf{0 . 9 2 - 0 . 9 8 )}$ & $\mathbf{0 . 0 0 0 7}$ \\
\hline Hypertension & $\mathbf{3 . 2 5}(\mathbf{1 . 0 7 - 9 . 8 )}$ & $\mathbf{0 . 0 3 7}$ \\
\hline CAD & $1.04(0.38-2.80)$ & 0.94 \\
\hline Diabetes mellitus & $0.53(0.23-1.23)$ & 0.143 \\
\hline Dyslipidemia & $0.42(0.13-1.34)$ & 0.15 \\
\hline Hemodialysis & $1.07(0.21-5.6)$ & 0.93 \\
\hline Current smoker & $0.75(0.23-2.32)$ & 0.61 \\
\hline Serum Creatinine & $1.05(0.76-1.44)$ & 0.76 \\
\hline eGFR & $0.98(0.96-1)$ & 0.16 \\
\hline Baseline AVA & $4.82(0.89-25)$ & 0.06 \\
\hline LVEF & $0.99(0.94-1.06)$ & 0.96 \\
\hline Aortic valve calcification & $0.82(0.31-2.13)$ & 0.68 \\
\hline
\end{tabular}

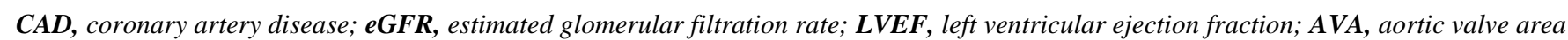

Table 4: Factors affecting rapid progression

Follow-up interval exceeded 4 years and included $>90 \%$ of patients $(\mathrm{n}=89)$. In the total group of 95 patients, mortality was $68 \%(\mathrm{n}=65), 25 \%$ $(n=24)$ received AVR and 6\% $(n=6)$ were lost to follow-up. The annual average rate of AVR was 5\%. Event-free survival with end-points of death $(n=65)$ or surgical/transcatheter AVR $(n=24)$ at 1,3 , and 5 years, respectively, was $93 \%, 66 \%$ and $40 \%$ for mild AS; $96 \%, 72 \%$ and $48 \%$ for moderate AS; and 93\%, 38\% and $24 \%$ for severe AS. Follow-up duration differed significantly between those with mild and severe AS $(\mathrm{p}=0.04)$ (Figure 1a). Among rapid progressors, mortality was $75 \%$, and $25 \%$ of patients underwent AVR. In the slower progressors, $68 \%$ died and $25 \%$ received AVR. Event-free survival at 1 year in slower progressors was $92 \%$ and in rapid progressors was $70 \%$. (Figure 1b).

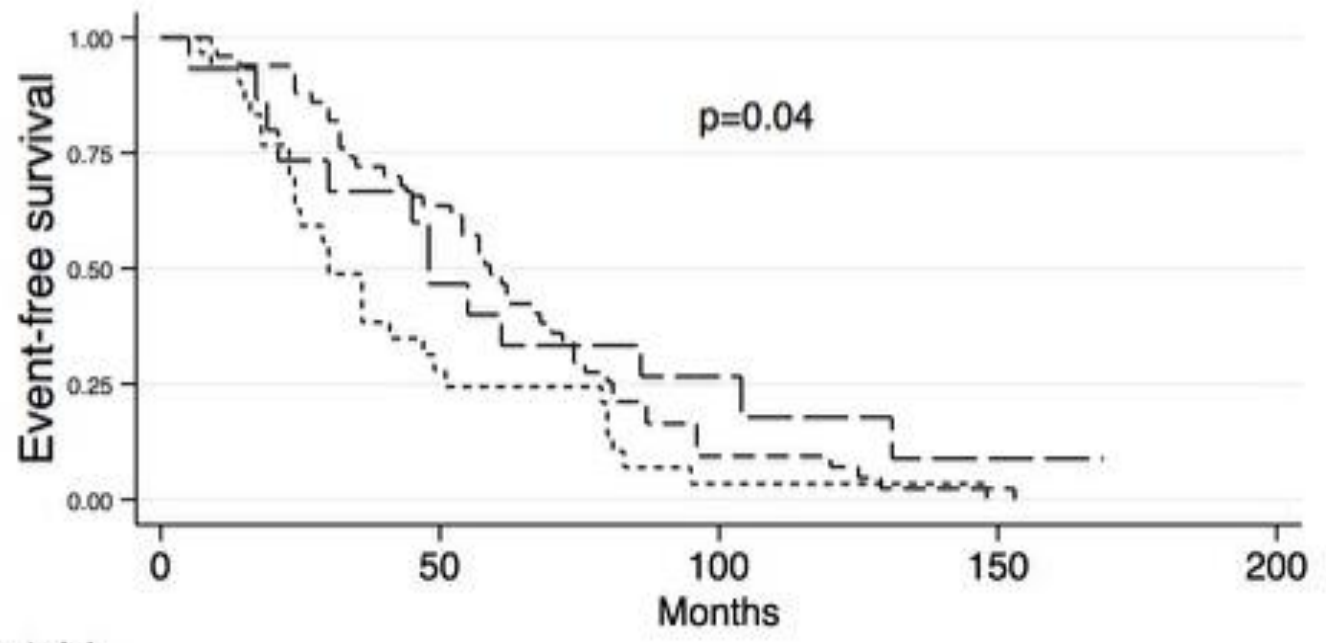

\begin{tabular}{|c|c|c|c|c|c|}
\hline \multicolumn{6}{|l|}{ Number at risk } \\
\hline Mild AS & 15 & 7 & 3 & 1 & 0 \\
\hline Moderate AS & 50 & 30 & 4 & 1 & 0 \\
\hline Severe AS & 30 & 8 & 1 & 0 & 0 \\
\hline
\end{tabular}

$$
\text { - }-- \text { Mild AS } \quad---- \text { Moderate AS …...... Severe AS }
$$

(AS, aortic stenosis)

Figure 1a 


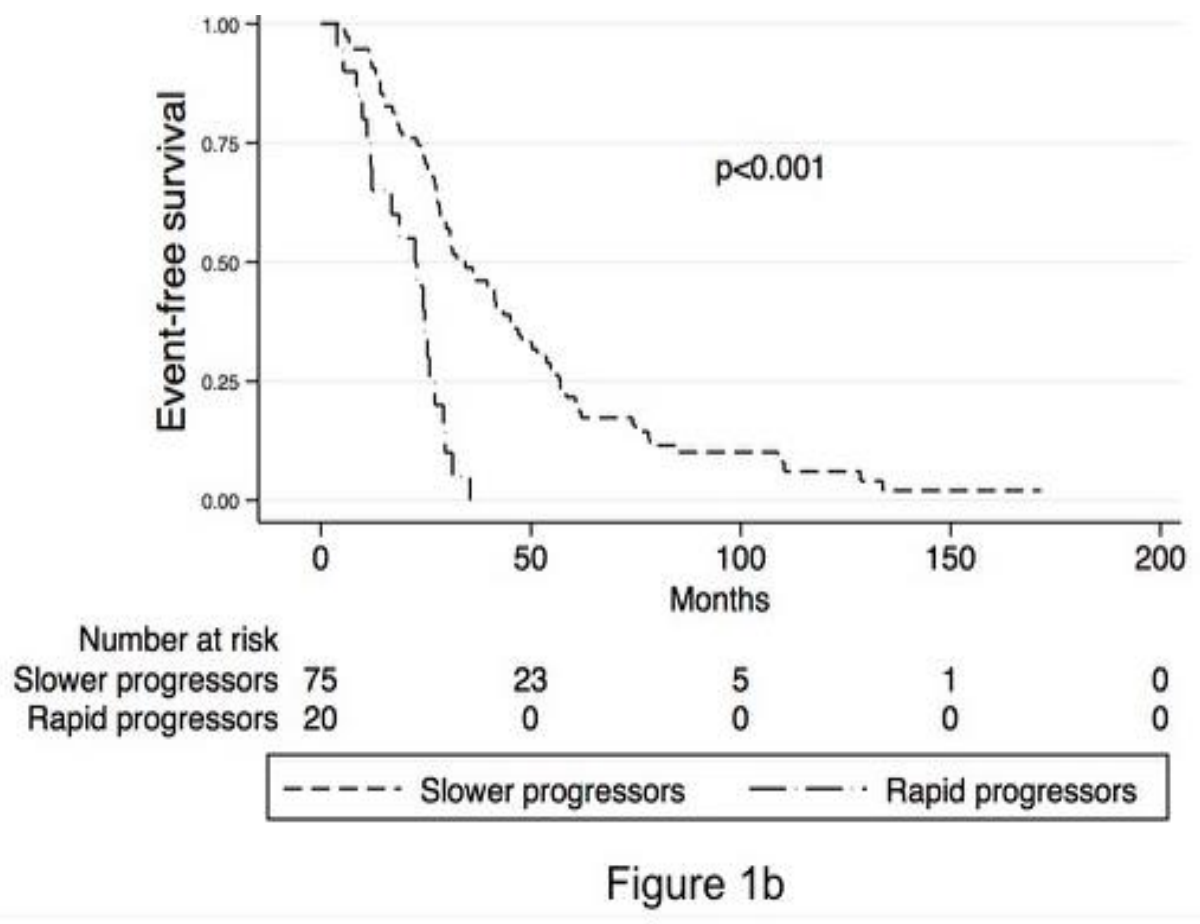

Figure 1b: Kaplan-Meier survival curves for rapid and slower progressors

\section{Discussion}

This study extends our understanding of AS progression and clinical outcomes in women. First, it enhances prior limited data on this disease and its related factors in females [22]; second, it includes one of the largest of the few AS cohorts limited to women; and third, the follow-up interval is among the longest in women with AS. Importantly, we found no prior studies that reported incidence of AVR specifically in women.

Our results show that the rate of AS progression in women was similar to previously reported findings in major studies of mixed sex cohorts [2, 3, $5,6]$. However, most of the latter investigations included a majority of men with no delineation of the sexes, precluding assessment of AS progression specifically in women. Additionally, many of these studies involved smaller follow-up intervals for assessment of progression than our study [2-7, 10, 12, 13, 23]. Further, our findings indicate that rapid AS progression was directly associated with hypertension and baseline AVA and inversely related to follow-up duration. Our results reveal that event-free survival at 5 years, including AVR and mortality, were significantly more favorable in women with mild and moderate baseline AS than in those with severe AS.

Our data revealed an average annual decrease in AVA of $0.14 \mathrm{~cm}^{2}(0.09$ to 0.21 ) during a follow-up of 4.5 years in 95 females. The annualized decrease in AVA for each of the 3 AS subgroups was greatest in patients with mild AS. Although prior studies reveal a wide range of AS progression in mixed sex cohorts, our findings in women are consistent with the predominant results of studies with rates of 0.11 to $0.14 \mathrm{~cm}^{2} / \mathrm{yr}$ $[2,3,5,6]$. However, some reports of AS progression in women noted rates as low as $0.04^{4}$ and $0.08 \mathrm{~cm}^{2} / \mathrm{yr}$ [22]. Rapid AS progression, defined as $\geq 0.20 \mathrm{~cm}^{2} / \mathrm{yr}$ [21], occurred in $20(21 \%)$ of our patients and was associated with a higher prevalence of hypertension and larger baseline AVA compared to their frequencies in the slower progressors.

In our patients, AS progression independently correlated with hypertension. Prior studies of mixed sex cohorts have been inconsistent regarding this relationship. Aronow and co-workers [32] found that hypertension (systolic $\geq 140 \mathrm{~mm} \mathrm{Hg}$ ) was positively associated with AS progression in all patients with mild baseline AS in a 2-year follow-up. By contrast in our cohort of mild, moderate and severe AS, follow-up was more than twice as long as that of Aronow et al. Other studies reported no correlation between hypertension and AS progression $[11,33]$ but one did note that hypertension was associated with increased mortality in patients with AS, especially in women [11].

As anticipated, the follow-up interval to AVR or mortality was considerably shorter in our patients with rapid progression than in the slower progressors $(20$ vs $42 \mathrm{mos}, \mathrm{p}<0.002)$. Unlike several previous observational studies of mixed gender, we did not find an association between AS progression and age [34,35], smoking [24,32], chronic kidney disease [13,14,24], diabetes mellitus [32] or dyslipidemia [36,37] (Table 3), which may be related to the size of our cohort. We found that AS progressed more rapidly in patients with mild than severe baseline AVA: 0.21 vs. $0.11 \mathrm{~cm}^{2} / \mathrm{yr}$. Bahler et al [13] also identified baseline AVA as an independent predictor of rapid AS progression, which they defined as $\geq 0.10 \mathrm{~cm}^{2} / \mathrm{yr}$. However, their study was shorter (1.8 yrs) and smaller (61 women) than ours.

Studies of long-term mortality and AVR specifically in women are few. In gender-mixed populations the annual rate of surgical AVR has varied widely $[3,7,11,34,38]$ from $4 \%$ to $25 \%$ in follow-up studies of $<1$ year [11] to $>5.0$ years [38] of follow-up. In our patients with AS varying from mild to severe, the annual rate of AVR was $5 \%$. In one investigation, a relatively high rate of AVR at 1 year $(\sim 25 \%)$ is likely accounted for by variables such as baseline severity of AS, rapidity of progression and symptoms [11]. The annual AVR of $10 \%$ reported by Pellikka et al [38] in 622 male and female patients was closer to ours $(5 \%)$ as was that of Rosenhek et al. in 176 mixed sex patients (4\%) [7].

Reports of mortality related specifically to AS in women are discordant. Of the 2 extended follow-up studies in women with AS, one for 5.4 yrs, reported that all-cause mortality was $31 \%$ lower in women than men [38] while the other, in which patients were observed for $3.2 \mathrm{yrs}$, detected no 
mortality, but the rate of AS-related events was almost twice as high in women than men[22]. Annual all-cause mortality in our total cohort was $15 \%$ and was highest in those with baseline severe AS (Figure 1a). To our knowledge, mortality in women with AS has not been previously addressed in terms of graded severity of baseline disease. By contrast, in mixed gender studies of AS, annual all-cause mortality has varied widely $[3,7,11,34,38]$ although rates in the most commonly cited studies are 2$4 \%[3,7]$. The differences between mortality in the latter studies are again likely related to multiple factors contributing to this endpoint. In this regard, Rosenhek et al [7] studied patients with mild and moderate AS, while our cohort included those with severe reduction in AVA. Additionally, the cohort of Otto et al. was approximately a decade younger than our patients [3].

Our study has several limitations. It is a single center retrospective investigation with the inherent limitations of this method. However, it adds information on an important subject with previously limited evidence. The study cohort is not large enough to exclude all factors that may influence AS progression, but we have assessed multiple potential variables. Our study did not include a control group of males but prior investigations are predominantly of males. Our results are based on changes in aortic valve area rather than gradients, although multiple measures of AS based on gradients and velocity have been published. The clinical outcomes and frequency of AVR reflect results from the preTAVR era but our data on rates of AS progression and rapid progression are relevant to contemporary management. Our cohort is limited in size number but it compares favorably in this regard with prior investigations of AS in women, and our follow-duration is longer than most studies in women. We did not find a relationship between diabetes and renal failure with AS progression, unlike other larger mixed sex studies, as ours is a smaller investigation and underpowered to determine predictors.

\section{Conclusions}

This study extends limited data on aortic stenosis in women by reporting average rate of progression of this lesion and associated factors, relation of aortic stenosis to severity of this disease, and identification of rapid and slower aortic stenosis progressors.

Acknowledgement: The project described was supported by the National Center for Advancing Translational Sciences, National Institutes of Health, through grant number UL1 TR001860. The content is solely the responsibility of the authors and does not necessarily represent the official views of the National Institutes of Health.

\section{Funding source(s): none}

All authors contributed to the production and analysis of the data, had acquisition to the data and contributed to production of the manuscript

\section{Declarations of interest: none}

\section{References}

1. Joint Task Force on the Management of Valvular Heart Disease of the European Society of C, European Association for CardioThoracic S, Vahanian A, Alfieri O, Andreotti F, Antunes MJ, Baron-Esquivias G, Baumgartner H, Borger MA, Carrel TP, De Bonis M, Evangelista A, Falk V, Iung B, Lancellotti P, Pierard L, Price S, Schafers HJ, Schuler G, Stepinska J, Swedberg K, Takkenberg J, Von Oppell UO, Windecker S, Zamorano JL, Zembala M. Guidelines on the management of valvular heart disease (version 2012). European heart journal 2012;33:24512496.
2. Faggiano P, Aurigemma GP, Rusconi C, Gaasch WH. Progression of valvular aortic stenosis in adults: literature review and clinical implications. Am Heart J 1996;132:408-417.

3. Otto CM, Burwash IG, Legget ME, Munt BI, Fujioka M, Healy NL, Kraft CD, Miyake-Hull CY, Schwaegler RG. Prospective study of asymptomatic valvular aortic stenosis. Clinical, echocardiographic, and exercise predictors of outcome. Circulation 1997;95:2262-2270.

4. Pellikka PA, Nishimura RA, Bailey KR, Tajik AJ. The natural history of adults with asymptomatic, hemodynamically significant aortic stenosis. J Am Coll Cardiol 1990;15:1012-1017.

5. Wagner S, Selzer A. Patterns of progression of aortic stenosis: a longitudinal hemodynamic study. Circulation 1982;65:709-712.

6. Rosenhek R, Binder T, Porenta G, Lang I, Christ G, Schemper M, Maurer G, Baumgartner H. Predictors of outcome in severe, asymptomatic aortic stenosis. N Engl J Med 2000;343:611-617.

7. Rosenhek R, Klaar U, Schemper M, Scholten C, Heger M, Gabriel $\mathrm{H}$, Binder T, Maurer G, Baumgartner H. Mild and moderate aortic stenosis. Natural history and risk stratification by echocardiography. European heart journal 2004;25:199-205.

8. Kamath AR, Pai RG. Risk factors for progression of calcific aortic stenosis and potential therapeutic targets. Int J Angiol 2008;17:6370 .

9. Shames S, Gillam LD. Sex differences in aortic valve calcification. Circ Cardiovasc Imaging 2013;6:8-10.

10. Cramariuc D, Rogge BP, Lonnebakken MT, Boman K, Bahlmann E, Gohlke-Barwolf C, Chambers JB, Pedersen TR, Gerdts E. Sex differences in cardiovascular outcome during progression of aortic valve stenosis. Heart 2015;101:209-214.

11. Rieck AE, Cramariuc D, Boman K, Gohlke-Barwolf C, Staal EM, Lonnebakken MT, Rossebo AB, Gerdts E. Hypertension in aortic stenosis: implications for left ventricular structure and cardiovascular events. Hypertension 2012;60:90-97.

12. Toyofuku M, Taniguchi T, Morimoto T, Yamaji K, Furukawa Y, Takahashi K, Tamura T, Shiomi H, Ando K, Kanamori N, Murata K, Kitai T, Kawase Y, Izumi C, Miyake M, Mitsuoka H, Kato M, Hirano Y, Matsuda S, Inada T, Murakami T, Takeuchi Y, Yamane K, Ishii M, Minamino-Muta E, Kato T, Inoko M, Ikeda T, Komasa A, Ishii K, Hotta K, Higashitani N, Kato Y, Inuzuka Y, Maeda C, Jinnai T, Morikami Y, Saito N, Minatoya K, Kimura T, Investigators CAR. Sex Differences in Severe Aortic StenosisClinical Presentation and Mortality. Circ J 2017;81:1213-1221.

13. Bahler RC, Desser DR, Finkelhor RS, Brener SJ, Youssefi M. Factors leading to progression of valvular aortic stenosis. Am J Cardiol 1999;84:1044-1048.

14. Urena P, Malergue MC, Goldfarb B, Prieur P, Guedon-Rapoud C, Petrover M. Evolutive aortic stenosis in hemodialysis patients: analysis of risk factors. Nephrologie 1999;20:217-225.

15. Whelton PK, Carey RM, Aronow WS, Casey DE, Jr., Collins KJ, Dennison Himmelfarb C, DePalma SM, Gidding S, Jamerson KA, Jones DW, MacLaughlin EJ, Muntner P, Ovbiagele B, Smith SC, Jr., Spencer CC, Stafford RS, Taler SJ, Thomas RJ, Williams KA, Sr., Williamson JD, Wright JT, Jr. 2017 ACC/AHA/AAPA/ABC/ACPM/AGS/APhA/ASH/ASPC/NMA/ PCNA Guideline for the Prevention, Detection, Evaluation, and Management of High Blood Pressure in Adults: A Report of the American College of Cardiology/American Heart Association Task Force on Clinical Practice Guidelines. J Am Coll Cardiol 2018;71:e127-e248.

16. Schiller NB, Shah PM, Crawford M, DeMaria A, Devereux R, Feigenbaum H, Gutgesell H, Reichek N, Sahn D, Schnittger I, et al. Recommendations for quantitation of the left ventricle by twodimensional echocardiography. American Society of Echocardiography Committee on Standards, Subcommittee on 
Quantitation of Two-Dimensional Echocardiograms. J Am Soc Echocardiogr 1989;2:358-367.

17. Cheitlin MD, Armstrong WF, Aurigemma GP, Beller GA, Bierman FZ, Davis JL, Douglas PS, Faxon DP, Gillam LD, Kimball TR, Kussmaul WG, Pearlman AS, Philbrick JT, Rakowski H, Thys DM. ACC/AHA/ASE 2003 guideline update for the clinical application of echocardiography--summary article: a report of the American College of Cardiology/American Heart Association Task Force on Practice Guidelines (ACC/AHA/ASE Committee to Update the 1997 Guidelines for the Clinical Application of Echocardiography). J Am Coll Cardiol 2003;42:954-970.

18. Lang RM, Badano LP, Mor-Avi V, Afilalo J, Armstrong A, et al. Recommendations for cardiac chamber quantification by echocardiography in adults: an update from the American Society of Echocardiography and the European Association of Cardiovascular Imaging. Eur Heart $J$ Cardiovasc Imaging 2015; 16:233-270.

19. Otto CM, Pearlman AS, Comess KA, Reamer RP, Janko CL, Huntsman LL. Determination of the stenotic aortic valve area in adults using Doppler echocardiography. J Am Coll Cardiol 1986;7:509-517.

20. American College of Cardiology/American Heart Association Task Force on Practice G, Society of Cardiovascular A, Society for Cardiovascular A, Interventions, Society of Thoracic S, Bonow RO, Carabello BA, Kanu C, de Leon AC, Jr., Faxon DP, Freed MD, Gaasch WH, Lytle BW, Nishimura RA, O'Gara PT, O'Rourke RA, Otto CM, Shah PM, Shanewise JS, Smith SC, Jr., Jacobs AK, Adams CD, Anderson JL, Antman EM, Faxon DP, Fuster V, Halperin JL, Hiratzka LF, Hunt SA, Lytle BW, Nishimura R, Page RL, Riegel B. ACC/AHA 2006 guidelines for the management of patients with valvular heart disease: a report of the American College of Cardiology/American Heart Association Task Force on Practice Guidelines (writing committee to revise the 1998 Guidelines for the Management of Patients With Valvular Heart Disease): developed in collaboration with the Society of Cardiovascular Anesthesiologists: endorsed by the Society for Cardiovascular Angiography and Interventions and the Society of Thoracic Surgeons. Circulation 2006;114:e84-231.

21. Lester SJ, McElhinney DB, Miller JP, Lutz JT, Otto CM, Redberg RF. Rate of change in aortic valve area during a cardiac cycle can predict the rate of hemodynamic progression of aortic stenosis. Circulation 2000;101:1947-1952.

22. Nguyen V, Mathieu T, Melissopoulou M, Cimadevilla C, Codogno I, Huart V, Duval X, Vahanian A, Messika-Zeitoun D. Sex Differences in the Progression of Aortic Stenosis and Prognostic Implication: The COFRASA-GENERAC Study. JACC Cardiovasc Imaging 2016;9:499-501.

23. Sherif MA, Zahn R, Gerckens U, Sievert H, Eggebrecht H, Hambrecht R, Sack S, Richardt G, Schneider S, Senges J, Brachmann J. Effect of gender differences on 1-year mortality after transcatheter aortic valve implantation for severe aortic stenosis: results from a multicenter real-world registry. Clin Res Cardiol 2014;103:613-620.

24. Palta S, Pai AM, Gill KS, Pai RG. New insights into the progression of aortic stenosis: implications for secondary prevention. Circulation 2000;101:2497-2502.

25. Ortlepp JR, Pillich M, Schmitz F, Mevissen V, Koos R, Weiss S, Stork L, Dronskowski R, Langebartels G, Autschbach R, Brandenburg V, Woodruff S, Kaden JJ, Hoffmann R. Lower serum $\mathrm{c}$ alcium levels are associated with greater $\mathrm{c}$ alcium hydroxyapatite deposition in native aortic valves of male patients with severe calcific aortic stenosis. The Journal of heart valve disease 2006;15:502-508.

26. Ortlepp JR, Hoffmann R, Ohme F, Lauscher J, Bleckmann F, Hanrath P. The vitamin D receptor genotype predisposes to the development of calcific aortic valve stenosis. Heart 2001;85:635638.

27. Fujise K, Amerling R, Sherman W. Rapid progression of mitral and aortic stenosis in a patient with secondary hyperparathyroidism. Br Heart J 1993;70:282-284.

28. Hekimian G, Boutten A, Flamant M, Duval X, Dehoux M, Benessiano J, Huart V, Dupre T, Berjeb N, Tubach F, Iung B, Vahanian A, Messika-Zeitoun D. Progression of aortic valve stenosis is associated with bone remodelling and secondary hyperparathyroidism in elderly patients--the COFRASA study. European heart journal 2013;34:1915-1922.

29. Rajamannan NM, Subramaniam M, Rickard D, Stock SR, Donovan J, Springett M, Orszulak T, Fullerton DA, Tajik AJ, Bonow RO, Spelsberg T. Human aortic valve calcification is associated with an osteoblast phenotype. Circulation 2003;107:2181-2184.

30. Massera D, Xu S, Bartz TM, Bortnick AE, Ix JH, Chonchol M, Owens DS, Barasch E, Gardin JM, Gottdiener JS, Robbins JR, Siscovick DS, Kizer JR. Relationship of bone mineral density with valvular and annular calcification in community-dwelling older people: The Cardiovascular Health Study. Arch Osteoporos 2017;12:52.

31. Mori H, Oku Y, Hashiba K, Seto M, Mameya G. [The relationship of osteoporosis to mitral annular and aortic valvular calcification in elderly women]. J Cardiol 1990;20:393-399.

32. Aronow WS, Ahn C, Kronzon I, Goldman ME. Association of coronary risk factors and use of statins with progression of mild valvular aortic stenosis in older persons. Am $J$ Cardiol 2001;88:693-695.

33. Tastet L, Capoulade R, Clavel MA, Larose E, Shen M, Dahou A, Arsenault M, Mathieu P, Bedard E, Dumesnil JG, Tremblay A, Bosse Y, Despres JP, Pibarot P. Systolic hypertension and progression of aortic valve calcification in patients with aortic stenosis: results from the PROGRESSA study. Eur Heart $J$ Cardiovasc Imaging 2017;18:70-78.

34. Peter M, Hoffmann A, Parker C, Luscher T, Burckhardt D. Progression of aortic stenosis. Role of age and concomitant coronary artery disease. Chest 1993;103:1715-1719.

35. Kume T, Kawamoto T, Okura H, Watanabe N, Toyota E, Neishi Y, Okahashi N, Yamada R, Yoshida K. Rapid progression of mild to moderate aortic stenosis in patients older than 80 years. $J \mathrm{Am}$ Soc Echocardiogr 2007;20:1243-1246.

36. Cowell SJ, Newby DE, Prescott RJ, Bloomfield P, Reid J, Northridge DB, Boon NA, Scottish Aortic S, Lipid Lowering Trial IoRI. A randomized trial of intensive lipid-lowering therapy in calcific aortic stenosis. N Engl J Med 2005;352:2389-2397.

37. Rossebo AB, Pedersen TR, Boman K, Brudi P, Chambers JB, et al. Intensive lipid lowering with simvastatin and ezetimibe in aortic stenosis. N Engl J Med 2008;359:1343-1356.

38. Pellikka PA, Sarano ME, Nishimura RA, Malouf JF, Bailey KR, Scott CG, Barnes ME, Tajik AJ. Outcome of 622 adults with asymptomatic, hemodynamically significant aortic stenosis during prolonged follow-up. Circulation 2005;111:3290-3295. 
This work is licensed under Creative Commons Attribution 4.0 License

To Submit Your Article Click Here: Submit Manuscript

DOI: $10.31579 / 2641-0419 / 147$
Ready to submit your research? Choose Auctores and benefit from:

* fast, convenient online submission

* rigorous peer review by experienced research in your field

* rapid publication on acceptance

* authors retain copyrights

* unique DOI for all articles

* immediate, unrestricted online access

At Auctores, research is always in progress.

Learn more www.auctoresonline.org/journals/clinical-cardiology-andcardiovascular-interventions 